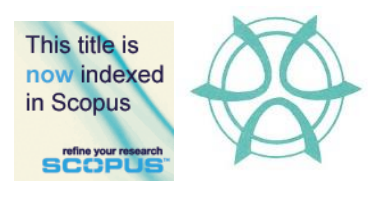

PLANNING MALAYSIA:

Journal of the Malaysian Institute of Planners

VOLUME 17 ISSUE 2 (2019), Page 237 - 248

\title{
GLOBAL ENVIRONMENTAL KUZNET CURVE FACTS AND CHALLENGES FOR THAILAND ON EMISSION REDUCTION PLAN
}

\author{
Chantamon Potipituk ${ }^{1}$ \\ ${ }^{1}$ Faculty of Architecture and Design \\ RAJAMANGALA UNIVERSITY OF TECHNOLOGY RATTANAKOSIN \\ THAILAND
}

\begin{abstract}
The correlation between country's gross domestic product and environment as reflected by carbon dioxide $\left(\mathrm{CO}_{2}\right)$ emission, also known as environmental Kuznet Curve (KC), shows a clear indication on the country's economic development and environmental protection status. In many aspects, economic growth and environment are not always going on a hand-in-hand mode. The most obvious example is seen in the use of natural resources to promote country's economic development, which is stand-off one another. However, environmental Kuznet Curve has shown a fact that environmental protection can be in parallel with the economic development given that country's economics does not largely depend on natural resources. We juxtapose the cross country data on gross domestic product (GDP) and $\mathrm{CO}_{2}$ emission from many offline and online documents. This paper explores the current facts of global environmental $\mathrm{KC}$ and corresponding possible consequences on Bangkok Metropolitan Emission reduction plan and implementation, towards environmentally sustainable development in Bangkok Metropolitan. By examining the global $\mathrm{KC}$, three levels of development of the individual country have been identified in terms of per capita GDP and $\mathrm{CO}_{2}$ emission. It shows that most Southeast Asian countries are at initial stage of KCbased development.
\end{abstract}

Keywords: Kuznet Curve, sustainable development, emission, planning system 
Chantamon Potipituk

Global Environmental Kuznet Curve Facts and Challenges for Thailand on Emission Reduction Plan

\section{INTRODUCTION}

A new paradigm in sustainable development has been released as Griggs (2013) defined the sustainable development in the Anthropocene which is "Development that meets the needs of the present while safeguarding Earth's life-support system, on which the welfare of current and future generations depends". This paradigm seems very much people centrist. Traditionally, sustainable development embraces three aspects of environment, economics and social (Pearce, Barbier, \& Markandya, 2013; Weaver, Jansen, Van Grootveld, Van Spiegel, \& Vergragt, 2017). Thus, within the sustainable development concept, the environment and economic development are expected to go in parallel. However, in fact, environment and development are two words that do not always go hand-in-hand in same direction (Sachs, 2015; Midlarsky, 2018). In most cases, these two entities go in diametrically opposite pathway (Smil, 2016). From the view point of human development, the relationship between environment and development is a sort of love-hate correlation. Development needs environment as resources, while human-being needs an environment and development to support their life. Economic development obviously needs resources for the progress of human capital advancement (Salehi-Isfahani, 2016).

Afrane (2012) asserted that during the low-hanging fruit era of oil production, while developed countries enjoyed blissful economic boom, most underdeveloped countries in Asia and Africa were still struggling for their independence. These two contrasting situations create substantial use of energy resources for logistic supplies and development. In the 1972 UN Conference on the Human Environment, world communities intended to bring the disparities between the industrialised and developing nations together into a common future to delineate the rights of the human family to a healthy and productive environment (Brundtland, 1987). By this platform, the environment and economic development gained equal opportunity to sustain. The sustainable development concept was accepted by the UN General Assembly in 1987.

The diametrical opposition of the natural resources use and economic growth, which is reflected in the global Kuznet Curve by individual country, has been basically the rationale of this study. This becomes the important information to examine the country's individual economic growth and environmental protection status. We intend to explore the dilemma of environmental conservation and economic development by examining current global environmental Kuznet Curve, as it has long been experienced by most developing world with the emphasis on Southeast Asian countries, particularly Thailand, and becomes the strong challenges now and the future. Global cross-country data on per capita gross domestic product (GDP) and carbon dioxide $\left(\mathrm{CO}_{2}\right)$ emission have been put side by side from the excerpt of offline and online documents and correlation analysis has been done. The correlation of per capita GDP and $\mathrm{CO}_{2}$ emission is important to examine the dilemma, as Adams (2001) highlighted that 
PLANNING MALAYSIA

Journal of the Malaysia Institute of Planners (2019)

the dilemma is a notable challenge for many developing countries, as it is problematic and complex to be optimised. To get the full picture of environmental deprivation as the result of economic development in global perspective, it would be wise if the discussion begins with the industrial revolution.

\section{THE GLOBAL OUTLOOKS}

\section{The Industrial Revolution}

The Industrial Revolution began in Europe in the 1700's, and spread to the rest of the world, beginning with the United States of America. McLamb (2011) asserted that the Industrial Revolution marked a major turning point in Earth's ecology and humans' relationship with their environment. The Industrial Revolution dramatically changed every aspect of human life and lifestyles (Hartwell, 2017). It was called revolution because of somewhat an abrupt change from agricultural to industrial activities, from manual means to machineries (Stearns, 2018). The effects on the environment would only be seen clearly years later (McLamb, 2011). The use of factories and mass production has also led to a depletion of certain natural resources, leaving the environment permanently damaged (EH Resources, 2015).

\section{Sustainable Development: The Dilemma of Developing Countries}

The sustainable development is a very philosophical concept. One of the popular definitions of the sustainable development is based on Brundtland's definition (1988) in Our Common Future, which defines sustainable development is development that meets the needs of the present without compromising the ability of future generations to meet their own needs. With a strong connection between 'present' and 'future' in the sustainable development concept, we must regard that the natural resources and environment are not the legacy of our ancestors, it rather belongs to our great-great grandchildren. By this philosophy, present generation must conserve existing natural resources and environment for future purpose. The use of natural resources is unavoidable. On the other hand, the uncontrolled natural resources utilisation would mechanically degrade the environment. Therefore, the natural resources utilisation for economic growth and development, amid reconcilable, could not go hand-in-hand with the environmental protection as depicted in Figure 1. Corbridge (1995) asserted that there is no doubt of the ethical domineering of tackling human poverty. Subscribing to this thought, an inquiry arises: must human poverty be eradicated with all cost? Including environmental degradation? If so, it is then acceptable when human poverty is alleviated with the expense of environment. The multiplier effects of alleviating human poverty are tremendous providing that good governance exists. As, poverty has gone, social welfare encroaches, then 
Chantamon Potipituk

Global Environmental Kuznet Curve Facts and Challenges for Thailand on Emission Reduction Plan

education level also improves. With higher education level, production of goods and services increases and economic productivity also increases.

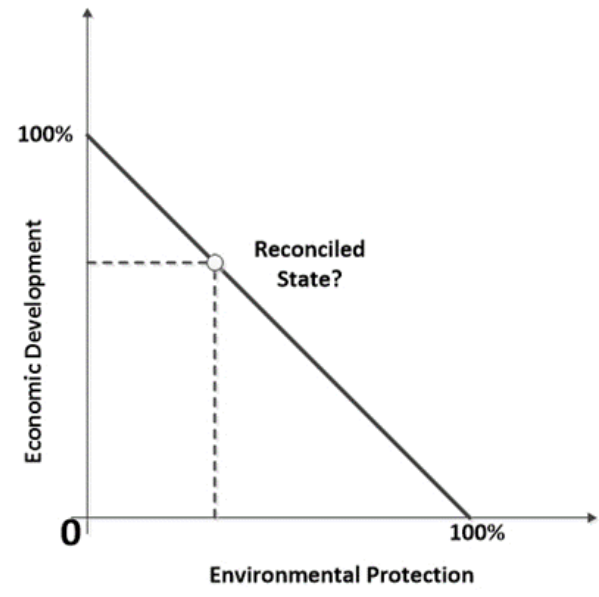

Figure 1 The dilemma between economic development and environmental protection Source: Permana (2018)

However, the actual process is not that easy as most developing countries lack good governance. Political instability, social unrest, terrorism, and corruption, are, among others, the persistent problems that most developing world must face. In reality, the so-called development process resulting in significant impacts on resources depletion but with obstinate poverty in both rural and urban citizens.

The developing countries seem difficult to cut the environmentdevelopment dilemma, and considered irreconcilable (Motel, Choumert, Minea $\&$ Sterner, 2014). For instance, Meadows, Randers and Meadows (2005) argued that rising world population, industrialisation, pollution, food production and resource depletion are impossible to continue and will sooner or later become unsustainable and collapse. However, we are confident that environmental protection and economic development are reconcilable. This fact can be easily found from the progress path of developed countries. Western European countries, for instance, experienced the industrial revolution era where the environmental degradation was beyond imagination, but now they are able to cope with the environmental problems while enjoy high economic growth. Barbier (1999) illustrated that the endogenous growth theory in the 1980's brought a fresh and very different perspective on the growth-environment relation, and the environment can equally influence the long-run growth path. Thus, it is perhaps rational to say that decoupling of environmental effects from growth is possible. The key-point is whether or not the authority would be able and willing to reconcile this dilemma in a sensible way. The proper path of 
PLANNING MALAYSIA

Journal of the Malaysia Institute of Planners (2019)

development on agriculture-based, mixed agriculture-industry based, industrybased, and then industry-cum-services as eventual process of development would be worth implementing.

\section{UNIFYING ECONOMIC GROWTH AND ENVIRONMENTAL CONSERVATION: LEARNING FROM CROSS-COUNTRY DATA}

There is always cure for all diseases except death. Although many people believe that environment-development dilemma is irreconcilable, but the ways to optimise it are always there. The balance on these two domains can always be negotiated. Using a cross-country data (note: the data could not be presented here as it too long for this limited space), a powerful example of GDP and level of environmental degradation as illustrated by Kuznet curve. Chow and Li (2014) defined the Environmental Kuznet Curve (EKC) as an empirical relationship during the course of economic development where per capita $\mathrm{CO}_{2}$ emissions first increases with per capita real GDP and later decreases with per capita real GDP. Kuznet curve has been fashionable to depict the sustainability (Farhani, Mrizak, Chaibi, \& Rault, 2014).

The curve in Figure 2 perfectly depicts the richer the greener and the poorer the "green". While the left-most part of the curve shows the countries with weak environmental protection, the right-most part of the curve shows the countries with strong protection. This curve tells us that a country with low GDP, the environmental problem i.e. environmental pollution in that country is also low, since no or few polluting industries are in place. The main economic activities are mostly agriculture-based products. The pollution level is therefore low. According to Tierney (2009), the peak point was about USD 8,000 based on GDP per capita in 1985 PPP. However, by using cross-country data in 2010-2015, the peak point is now higher, which is about USD 50,000. The outliers such as Bahrain, Brunei, Oman, Qatar and United Arab Emirates were excluded from the analysis. They are high income countries but their per capita emission is high. 
Chantamon Potipituk

Global Environmental Kuznet Curve Facts and Challenges for Thailand on Emission Reduction Plan

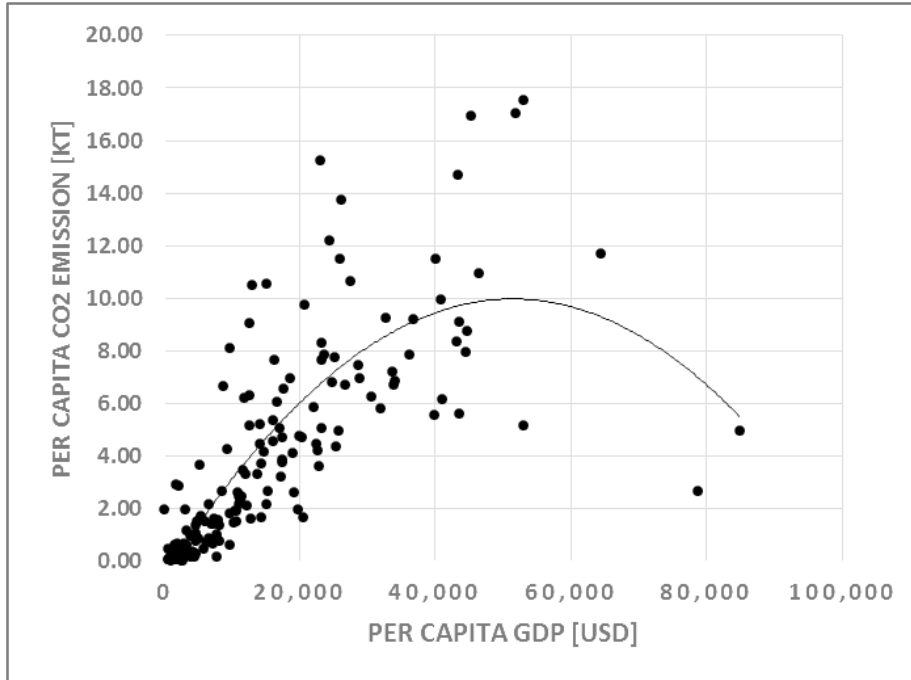

Figure 2 Global Environmental Kuznet Curve (based on cross country data)

Although perhaps the only indicator of $\mathrm{CO}_{2}$ emission is insufficient to comprehensively show the characteristics of the EKC, however, it seems that some recent studies done in developing cities show that there is indeed a strong connection between economic development, as reflected in the land use changes, and $\mathrm{CO}_{2}$ emission stemming from transport sector (Permana, Perera, Aziz, \& Ho, 2015a; Permana, Perera, Aziz, \& Ho, 2015b). However, one can argue that the poverty strongly associates with the environmental degradation (see Duraiappah, 1998; Ravnborg, 2003; Aaron, 2005).

\section{DIFFERENT COUNTRIES, DIFFERENT NEEDS: THAILAND CASE, LEARNING FROM GLOBAL EKC}

In consultation with the Kuznet curve, at any given point or period, different countries have different level of development. Thus they have different needs. Switzerland, for example, with per capita GDP PPP 2010 was about USD 84,000, per capita $\mathrm{CO}_{2}$ emission was only 4.95 tonnes. On a different side, Burundi emitted 0.35 tonne of $\mathrm{CO}_{2}$ per capita while its per capita GDP was USD 870. Burundi, for sure, will not emphasise their development over environmental protection, since Burundi needs to strongly struggle with the acute poverty problem.

Figure 3 is composed of two super-imposed graphs; (1) countries with different per capita GDP ordered from the smallest to the largest and (2) correlation between environmental conservation and natural resources use i.e. economic growth. It shows that countries with GDP per capita less than USD 10,000 are considered as at the initial stage of development. At this stage, the 
economic growth is largely supported by the use of natural resources. Thus, we can expect that in the countries of this stage, the environmental degradation is substantial. However, environmental pollution can be low as fewer industries are in place. The countries are incapable of liberating themselves from the dependency on natural resources use. If the government wisely use the natural resources for mere economic and human capital development, the subsequent stage can be smoothly accomplished. However, in the repressive and corrupt government, the depletion of natural resources use will be much faster than the improvement of people's wellbeing and economic growth.

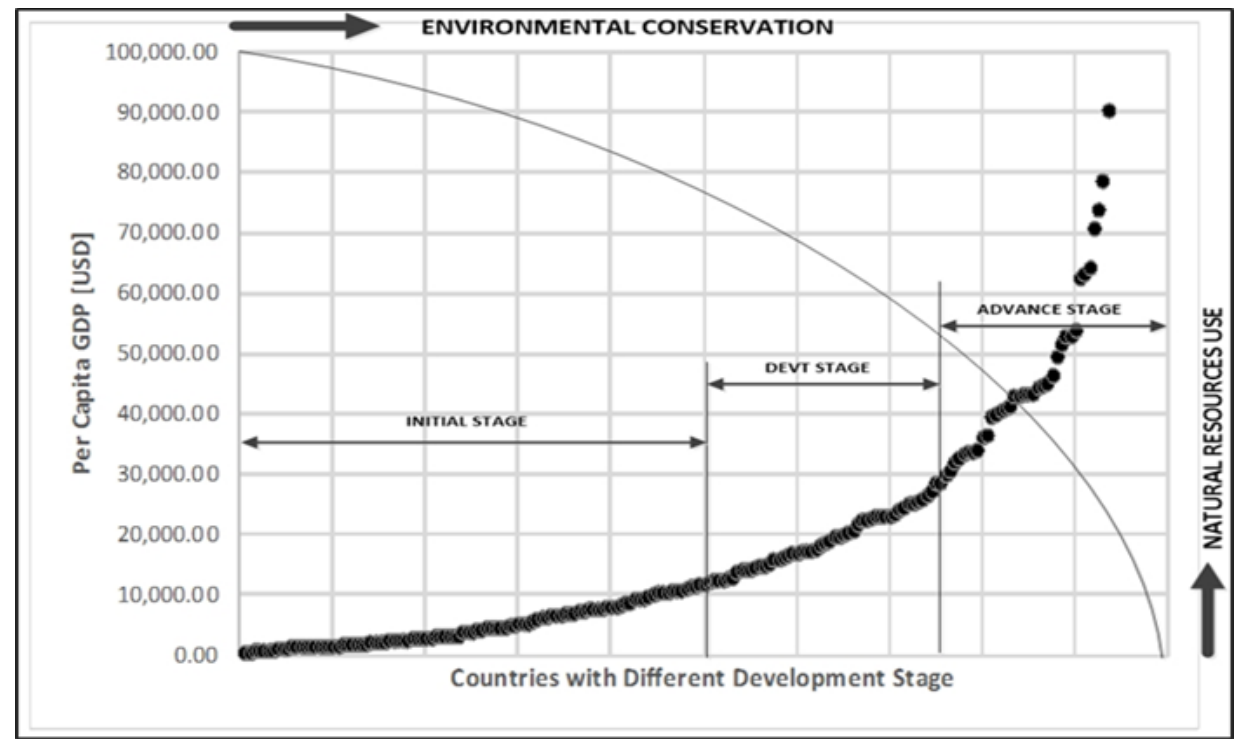

Figure 3 Country's stage of development (based on cross-country data)

The countries will be posed in development stage when their economic growth is not fully dependent on natural resources. Their GDP is about USD 10,000 to 30,000 . New industrialising countries will be born at this stage, and the natural resources use and environmental pollution will be more at the commencing stage since industrial sector predominates the economic growth. At the advance stage, when per capita GDP more than USD 30,000, the dependency on natural resources use will be less, although the use of natural resources could not be totally avoided. Both environmental degradation and environmental pollution will be less, because of the ability of the countries to employ greener and cleaner industries. However, there are some countries considered as outliers. These countries enjoy high per capita GDP while the level of environmental pollution is also high. These countries are mostly dependent on single vital natural resources such as oil. These countries do not either place environmental 
Chantamon Potipituk

Global Environmental Kuznet Curve Facts and Challenges for Thailand on Emission Reduction Plan

protection as priority or have technological independency from countries. Or, simply the total population of the country is too small, and industries are mostly run by expatriates.

From the cross-country data presented, it is fair to say that optimising the natural resource use and environmental degradation or pollution is a dynamic process depending on the development stage of the country. One assumption on this circumstances is that a country will follow a traditional stage of development i.e. [agriculture]-[agriculture + industry]-[industry + service]. This is what EKC would eventually affect the emission reduction programmes in a country.

Thailand, with per capita GDP of about USD 6,500 (in 2017) and per capita emission is about 4.3 tonnes $\mathrm{CO}_{2} \mathrm{E}$, is presently at the initial stage of development, in which agricultural-based and industrial-based economy can be considered balanced, but leading towards agro-industry and industrial-based economy. By this stage, the Thailand plan to reduce $\mathrm{CO}_{2}$ emission is at very fundamental stage covering all possible sectors. The plan to reduce the $\mathrm{CO}_{2}$ emission is covered in the Thailand Voluntary Emission Reduction Program (TVER). The objectives of T-VER are basically; (1) to push the development of cobenefit greenhouse gaseous (GHG) emission reduction projects and programmes through certifying carbon credits, (2) to promote voluntary Carbon Market in Thailand, (3) to raise the awareness of climate change by stakeholders, (4) to encourage public and private sector involvement, and (5) to prepare all stakeholders for the future new agreement in Global GHG emission reduction.

The types of projects and programmes covered by T-VER include energy efficiency for households, industries and commerce; alternate energy covering low-emission energy and green energy; renewable energy such as solar power, wind power and biogas; transportation by promoting more public transport e.g. extension of BTS and MRT in Bangkok Metropolitan Region; and waste management by promoting sustainable solid waste management. T-VER has been implemented by Bangkok Metropolitan Authority and Nakhon Ratchashima City Authority; land use and forestry associated programmes have been implemented in the whole of Thailand; and agriculture programmes e.g. the use of non-GHG fertilisers. Many private companies, government-owned companies, government organisation have involved in the implementation of the projects. However, the results could not be reported at this stage since the projects are still on-going.

\section{LESSONS LEARNT FROM GLOBAL EKC FATCS}

\section{Sustaining the Potentials}

Every country and nation has its own potentials for the advancement of their development. The potentials of the country can be, and definitely, natural resources, human resources, and technological know-how. Unfortunately, the developing world lacks human resources and technological know-how. Thus, 
PLANNING MALAYSIA

Journal of the Malaysia Institute of Planners (2019)

natural resources as the only asset, must be utilised wisely and sustainably. Natural resources must be able to develop human resources, because of the multiplier effect properties of human resources development. With high quality of human resources, technological know-how to develop the country is made available. Japan has no natural resources and a natural disaster vulnerable country. But, Japan has high quality of human resources. Thus, natural resources roles in their development process can be nullified. United Arab Emirates, Qatar and Oman has natural resources. But this potential is not used to develop the capacity of their nations. In the short-term, the need of human resources to run the country is met by hiring high quality expatriates. Financial reward is one of the strongest attractions for professional. UAE, Qatar and Oman are practically run by expatriates who mostly come from developed countries of Northern America and Western Europe. The number of local people in these countries is less than the number of expatriates and migrants workers. Their policies are good for the short-term but not for the long-term, unless they also conducted an intensive transfer of knowledge from the professional expatriates to local people.

\section{Environment: A Resource for Development}

Natural resources are definitely vital prerequisite for the development process. No one can avoid the use of natural resources to meet their needs, not even developed countries with advance technology know-how. However, not all resources provided by nature are renewable, most of them are in non-renewable state. Presently, to harvest renewable energy is very expensive and most of them are at preliminary stage. The use of sun and wind energy is still not that advance and with limited energy production, unlike nuclear energy or hydropower energy. Hydropower energy is limited by nature, and it will be no more expansion someday after no more water with potential energy exists. Oil as a prominent source of energy will soon deplete. The replenishment will take millions of years. Thus it is considered as non-renewable energy. On the other hand, the use of renewable energy is not ready yet with respect to technology and mass production. There is almost no low-cost technology presently to utilise renewable energy. Therefore, there is only small fraction of renewable energy use in the world, although there is significant increases. For example, in 2012 the percentage of renewable energy for electricity was about $12.2 \%$ and in 2014 this percentage was about $22 \%$ (REN 21, 2014).

\section{Producing More with Less}

Efficiency is one way to conserve the environment. Efficiency can support sustainability, including sustainable consumption and production. Sustainable consumption and production is about "the use of services and related products, which respond to basic needs and bring a better quality of life while minimising the use of natural resources and toxic materials as well as the emissions of waste 
Chantamon Potipituk

Global Environmental Kuznet Curve Facts and Challenges for Thailand on Emission Reduction Plan

and pollutants over the life cycle of the service or product so as not to jeopardise the needs of further generations" (Oslo symposium, 1994). These flowery words can be shortened by saying that we must produce more with less. The key is efficiency in both production and consumption. When we observe a product for the whole of its life-cycle, we will immediately identify that the production process from exploiting raw material to end of lifetime of the product (cradle-tograve process) involves a number of inputs i.e. material and energy, and also residuals. Technology, to certain extent, is able to increase the productivity of a stuff that has actually limited capacity. One example is the productivity of farm land. Before the introduction of technology, a hectare of farm land can produce only 5 tonnes of paddy per season. But with the application of technological product for enriching soil nutrients i.e. fertiliser along with good irrigation system, the farm land production can be improved up to 9 tonnes per hectare per season. This case happened in Thailand and some parts of Indonesia.

\section{Implications to Thailand Country's Planning and Southeast Asia's Perspective}

Understanding the facts of Global Environmental Kuznet Curve, it can be concluded that for the Thailand's case, the country is presently moving towards industrial country stage, with agro-industry as the core activities. Additionally, by referring to KC-based development, Thailand is considered as the country at initial stage of the balance between economic development and environmental protection. The planning system of Thailand, in which Department of Town and Country Planning, as the sole agency in charge of country planning, has been comprehensively accommodating the programmes of emission reduction in the plan, as reflected, for example in the T-VER, which involving various stakeholders of the country. As a country at the development stage (referring to Figure 3), Thailand emphasises economic growth with attention to environmental protection and conservation. Malaysia has been on the right track towards emission reduction without hampering the economic growth, by introducing its voluntary reduction of emissions intensity of GDP by up to $40 \%$ by 2020 through various programs (MNRE, n.d). The KC also shows Malaysia at the end-phase of initial stage towards next level of development.

\section{ACKNOWLEDGEMENT}

We acknowledge the support of Rajamangala University of Technology Rattanakosin, without which this research would not have been accomplished. 


\section{REFERENCES}

Aaron, K. K. (2005). Perspective: Big oil, rural poverty, and environmental degradation in the Niger Delta region of Nigeria. Journal of Agricultural Safety and Health, $11(2), 127-134$.

Adams, W. M. (2001). Green development: Environment and sustainability in the Third World (2nd Edition). London: Routledge.

Afrane, G. (2012). Examining the potential for liquid biofuels production and usage in Ghana. Energy Policy, 40, 444-451.

Barbier, E. B. (1999). Endogenous growth and natural resource scarcity. Environmental and Resource Economics, 14(1), 51-74.

Brundtland, G. H. (1987). Report of the World Commission on Environment and Development: Our common future. Retrieved February 11, 2018 from http://www.un-documents.net/our-common-future.pdf

Chow, G. C., \& Li, J. (2014). Environmental Kuznets Curve: Conclusive economic evidence for CO2. Pacific Economic Review, 19, 1-7.

Corbridge, S. (1995). Development studies: A reader. London: Arnold.

Duraiappah, A. K. (1998). Poverty and environmental degradation: A review and analysis of the nexus. World Development, 26(12): 2169-2179.

Environmental History Resources [EH Resources] (2015). Retrieved February 11, 2018 from http://www.eh-resources.org/timeline/timeline_industrial.html ().

Farhani, S., Mrizak, S., Chaibi, A., \& Rault, C. (2014). The environmental Kuznets curve and sustainability: A panel data analysis. Energy Policy, 71, 189-198.

Griggs, D. (2013). Sustainable development for people and planet. Nature, 495, 305-307.

Hartwell, R. M. (2017). The industrial revolution and economic growth. London: Routledge.

McLamb, E. (2011). The ecological impact of the industrial revolution. Retrieved February 11, 2018 from http://www.ecology.com/2011/09/18/ ecologicalimpact-industrial-revolution/

Meadows, D. H., Randers, J., \& Meadows, D. L. (2005). The limits to growth: The 30year update revised edition. London: Earthscan.

Midlarsky, M. I. (2018). Democracy and the environment. In P. Diehl (Ed.), Environmental conflict: An anthology (pp. 155-178). London: Routledge.

MNRE (n.d.). Malaysia's Second National Communication (NC2) submitted to the United Nations Framework Convention on Climate Change (UNFCCC). Putrajaya: Ministry of Natural Resources and Environment of Malaysia.

Motel, P. M., Choumert, J., Minea, A., \& Sterner, T. (2014). Explorations in the environment-development dilemma. Environmental and Resource Economics, $57,479-485$.

Pearce, D., Barbier, E., \& Markandya, A. (2013). Sustainable development: Economics and environment in the Third World. London: Routledge.

Permana, A. S., Perera, R., Aziz, N.A., \& Ho, C. S. (2015a). Creating the synergy of land use, transport, energy and environment elements towards climate change cobenefits. International Journal of Built Environment and Sustainability, 2(1):1728. 
Chantamon Potipituk

Global Environmental Kuznet Curve Facts and Challenges for Thailand on Emission Reduction Plan

Permana, A. S., Perera, R., Aziz, N.A., \& Ho, C. S. (2015b). Corroborating the land use change as primary determinant of air quality degradation in a concentric city. International Journal of Built Environment and Sustainability, 2(2):75-84.

Oslo Symposium (1994). Assessed on March 17, 2018 at http://www.unep. org/rio20/About/SustainableConsumptionandProduction/tabid/102187/Default. aspx

Ravnborg, H. M. (2003). Poverty and environmental degradation in the Nicaraguan hillsides. World Development, 31(11), 1933-1946.

Renewable Energy Network for 21 Century [REN 21] (2014). Renewables 2014 global status report.

Sachs, W. (2015). Planet dialectics: Explorations in environment and development. London: Zed Books Ltd.

Salehi-Isfahani, D. (2016). Human development in the Middle East and North Africa. In The new Palgrave dictionary of economics (pp. 1-14). London: Palgrave Macmillan.

Smil, V. (2016). China's environmental crisis: an enquiry into the limits of national development. London: Routledge.

Stearns, P. N. (2018). The industrial revolution in world history. London: Routledge.

Weaver, P., Jansen, L., Van Grootveld, G., Van Spiegel, E., \& Vergragt, P. (2017). Sustainable technology development. London: Routledge

Received: $5^{\text {th }}$ March 2019. Accepted: $20^{\text {th }}$ August 2019. 